\title{
MATHEMATICAL MODELS FOR DETERMINATION THE CRITICAL PERIOD OF WEED COMPETITION IN BROADCASTED SEEDED RICE (Oryza sativa L.) \\ Tagour, R. M. H. ${ }^{1}$ and I. M. EL-Metwally ${ }^{2}$ \\ 1Weed Research Laboratory Central, Agric. Res. Center, Giza, Egypt. 2 Botany Dept., National Research Center, Dokki, Giza, Egypt
}

\begin{abstract}
Two weed competition experiments in broadcasted seeded rice were conducted during 2007 and 2008 summer seasons at EL-Serw Station, Damietta Governorate, Egypt. Ten manual weed competition and weed removal at early or late times after sowing were: - weed competition for the whole season, weed competition for 4, 6, 8 and 10 weeks from sowing, weed free for 4, 6, 8 and 10 weeks from sowing and weed free for the whole season, to determine when a natural infestation of weeds start to reduce rice yield and when stopped without yield losses in broadcasted rice. Dominant major weeds in experimental fields were barnyardgrass Echinochloa crus galli (L.)Beauv, jungle rice (Echinochilon columum (L.) Link), small flower umbrella plant (Cyperus difformis (L.), nutsedge (Cyperus longus (L.) and hemeira Dicanthium annulatum.

Results showed that the maximum yield losses were 43 to $46 \%$ due to weed infestation in field experimental with average 16 ton/fed fresh weight of total weeds in both seasons, respectively, as compared to weed free plots. Using classical approach for determination the critical periods indicated that yield losses start after 3 weeks from sowing and stopping yield losses due to weed competition after 8 weeks from sowing. Using regression approach showed that the mathematical calculated model for study the relationship between weed competition or weed removal period and grain yield (ton/fed), straw yield (ton/fed) of broadcasting seeded rice was fit quadratic function. These functions had $R^{2}$ value $0.983,0.899$ and $0.994,0.986$ in the first season, $0.990,0.879$ and $0.993,0.986$ in the second season for grain yield and straw yield, respectively. Application this function showed that to maintain $95 \%$ of maximum grain yield of rice, growers rice should start controlling weeds not later than two weeks and continue until 7 weeks from sowing to maintain the rice potential yields by applying early suitable recommended post emergence herbicides for controlling the abovementioned spectrum of weeds and strategies of weeds management.
\end{abstract}

\section{INTRODUCTION}

Rice crop is drastically affected by weeds, which can cause yield losses due to weed competition by 20 to 95\% (Gogoi et. al., 1996 and Karim et. al., 1998). Rice is growing in Egypt, mainly by transplanting method, but this method is costably and there was a need to increase the area of broadcasted rice. The main obstacle in this method is the high weed 
infestation and the best way is to determine the magnitude of yield losses and the critical control period in broadcasted rice through applying integrated control strategies to avoid the abuse of herbicides and such yield losses.

Earlier studies in this situation by (Vega et al., 1967) which show that rice yield is reduced for only short time after planting, should be weeded for 40 days to obtain yield reached a maximum and there is no benefit from weeding for an additional 10 days and these is no yield reduction when weeds allow to grow up 20 days after planting and then removed and considered the critical period for weed control as being 30 days to 40 days after crop emergence. Broadcasted such in seeded rice needed heavily weeding and herbicides because broadcasted seeded rice consider as inadequate competitor as in transplanting rice. Thus, research was needed to determine the critical period for weed control in rice fields. Burnside et al., 1998 , mentioned that research was needed to determine the critical period for control in any field crop is usually done by (1) keeping the crop free from weeds until certain predetermine times and then allowing weeds to grow and (2) allowing the weeds to emerge and grow with the crop for certain predetermined times, after which all weeds are removed in a timely manner until the end of growing season, Nieto et al. (1968) and Singh et al. (1996), the time interval between (1) and (2) is the critical period for weed control. (Zimdahl, 1988) mentioned that, the historically critical periods have been calculated by mean separations (hereafter referred to as the classical approach) in experiments that evaluated the impact time of weed emergence and time of removal on crop yields. Using the classical approach, it is possible to identify it period within no statistically detectable yield losses occur. The use at regression analysis (referred to as the functional approach), (Cousens 1985a; Knezevic et al., 2002 and Mekky et al., 2005).

The objectives of this study were to determine (1) when the early emerging weeds first began to reduce broadcasted seeded rice (2) when the late emerging weeds no longer reduced broadcasted rice and (3) by using the above mentioned approaches to the critical period for control weeds community in seeded broadcasted rice production fields in Egypt.

\section{MATERIALS AND METHODS}

Two field experiments were carried out during summer seasons of 2007 and 2008 at El-Serw Agricultural Research Station, Agricultural Research Center farm, Damietta Governorate, Egypt to determine the critical period of weed competition in broadcasted rice. The soil texture was clay (Table 1).

Table 1: Chemical and physical analyses of the used soil during the two growing seasons

\begin{tabular}{|c|c|c|c|c|c|c|c|c|c|c|c|}
\hline \multicolumn{5}{|c|}{ Particle Size distribution } & \multirow{2}{*}{$\begin{array}{c}\text { PH } \\
\text { Of soil } \\
\text { Susp } \\
1: 25\end{array}$} & \multirow[b]{2}{*}{$\begin{array}{c}\text { E.C } \\
\text { ds } / m \\
\text { At } 25 c^{\circ}\end{array}$} & \multirow[b]{2}{*}{$\begin{array}{c}\text { MO } \\
\%\end{array}$} & \multirow{2}{*}{\begin{tabular}{|c|} 
Total \\
N \\
$\%$
\end{tabular}} & \multirow{2}{*}{$\begin{array}{c}\text { Available } \\
\mathbf{N} \\
\text { ppm }\end{array}$} & \multirow{2}{*}{\begin{tabular}{|c|} 
Available \\
$\mathbf{P}$ \\
$\mathbf{p p m}$
\end{tabular}} & \multirow{2}{*}{$\begin{array}{c}\text { Available } \\
\mathrm{K} \\
\mathrm{ppm}\end{array}$} \\
\hline $\begin{array}{l}\text { Ooarse } \\
\text { sand } \\
\%\end{array}$ & \begin{tabular}{|c|} 
Fine \\
sand \\
$\%$
\end{tabular} & $\begin{array}{l}\text { Silt } \\
\%\end{array}$ & Clay & & & & & & & & \\
\hline 0.24 & 17.65 & 7.5 & & Iay & & & 1.20 & & & & \\
\hline
\end{tabular}


The schemes of treatments were followed according to Dawson (1970) where two basic types of treatments. In one type of treatments the crop is kept weed free for different time after planting and then allowed to become weedy. Conversely, in the other type of treatments weeds are allowed to grow with a crop for different period, following the competitive period, crop is maintained weed free for the remainder of the growing season as follow:

Each experiment included ten treatments which were:

1- Weed competition for the whole season.

2- Weed competition for 4 weeks from sowing.

3- Weed competition for 6 weeks from sowing.

4- Weed competition for 8 weeks from sowing.

5- Weed competition for 10 weeks from sowing.

6 - Weed free for 4 weeks from sowing.

7- Weed free for 6 weeks from sowing.

8- Weed free for 8 weeks from sowing.

9- Weed free for 10 weeks from sowing.

10- Weed free for the whole season.

Rice c.v. Giza 178 was sown on May $30^{\text {th }}$ in both seasons at $70 \mathrm{~kg} /$ feddan. Plot area was $16 \mathrm{~m}^{2}(4 \mathrm{~m} \times 4 \mathrm{~m})$. Recommended cultural practices were followed except the treatments under study to maintain optimum crop growth. The experiment design was randomized complete block design with three replicates. Weeds were identified and classified into the total fresh weights of weeds were recorded was used. Rice was harvested at September $20^{\text {th }}$ in both seasons.

\section{Data recorded}

\section{Weed survey}

Weeds were hand pulled from one square meter chosen at random in each plot, identified and classified to species annual total weeds $\left(\mathrm{g} / \mathrm{m}^{2}\right)$.

II. Growth characteristics and yield components of rice plants were recorded at harvest:-

1- Plant height $(\mathrm{cm})$.

3- Panicle length $(\mathrm{cm})$.

2- Dry weight of whole plant (g).

5- 1000-grain weight (g).

III.:- yield

1- Grain yield was calculated (t/feddan).

2- Straw yield was calculated (t/feddan).

Grain yield $\%=$ (grain yield in treatment plots $\div$ grain yield weed free plots $) \times$ 100

All obtained data were statistically analyzed according to (Snedecor and Cochran 1967) LSD at $5 \%$ level of significance was used to compare between means.

Mathematical models: - For determine critical period of weed competition in rice, two approaches used as: -

1- Classical biological approach: -

The critical period has been defined as the period during which weeds must be controlled to prevent yield losses. Since the concept of critical period was introduced, it has been used to determine the period when control 
operation should be carried out minimize yield losses for rice crop (Zimdahl, 1988). The critical period for weed control as a "window" in the crop cycle during which weeds must be controlled to prevent unacceptable yield losses (Knezevic, 2000).

2- Regression approach: - According to Singh et al. (1996) the relationship between crop yields $(\mathrm{Y})$ and duration of weed-free or weed-competition period $(X)$ by either function $\tilde{y}=a+b x+c x^{2}$, where the parameters $\beta 0$ and $B 1$ represent intercept and slope of regression of yield on the duration, respectively. Or by the quadratic function $\tilde{y}=a+b x$ and a logistic function $Y$ $=A+C /(1+e-B(X-M))$, where $X$ is duration of weed-competition period, parameter $\mathrm{M}$ is the point of inflection of the logistic curve, $\mathrm{B}$ shape parameter, $A$ or $A+C$ is asymptotic yield depending on whether $B$ is negative or positive and $\mathrm{C}$ is twice the difference of yield at the point of inflection and asymptotic yield.

\section{RESULTS AND DISCUSSION}

The major weed species presented in the experimental area were common barnyard grass Echinochloa crus - galli (L.)Beauv, jungle rice, (Echinochilon columum (L.)), Link small flower umbrella plant (Cyperus difformis (L.)), nut sedge (Cyperus longus (L.)) and (hemeira) Dicanthium annulatum. Weed infestation was high in both seasons 2007 \& 2008 carried to 3769 and $3770 \mathrm{~g} / \mathrm{m}^{2}$, respectively, and this very suitable to determine the critical period.

\section{I - Effect of weed competition on growth characters and yield components of rice:}

Data in Table 2 indicated that plant height, dry weight of rice plant, panicle length, number of panicles $/ \mathrm{m}^{2}$, and 1000 -grain weight of rice plants, grain and straw yields were significantly affected by weed competition and removal duration at harvest in both seasons. The treatments of weed free and weed removal periods significantly increased plant height, dry weight of rice plant, panicle length, number of panicles $/ \mathrm{m}^{2}$, and 1000-grain weight than weed competition for the whole season (unweeded check) in both seasons. The highest results were produced by weed free treatments and weed removal at 4 and 6 weeks from sowing, when compared with the other weed removal treatments as well as, weed competition for the whole season (unweeded check) in both seasons. On the contrary, the lowest value in this respects in weed removal treatments at 8 and 10 weeks from sowing and weed competition for the whole season (unweeded check). Unweeded treatment reduced the lowest thicker of this trail. 
Table 2: Effect of weed competition duration on growth characters and yield components of broadcasting rice plants at harvest, during 2007 and 2008 summer seasons.

\begin{tabular}{|c|c|c|c|c|c|}
\hline $\begin{array}{l}\text { Weed competition \& Weed removal } \\
\text { Times }\end{array}$ & $\begin{array}{c}\text { Plant } \\
\text { height } \\
\text { (cm) }\end{array}$ & \begin{tabular}{|} 
Dry \\
weight of \\
rice \\
plant(g)
\end{tabular} & $\begin{array}{c}\text { Panicle } \\
\text { length } \\
\text { (cm) }\end{array}$ & $\begin{array}{c}\text { No. of } \\
\text { Panicles } \\
/ \mathbf{m}^{2}\end{array}$ & $\begin{array}{c}\text { Weight of } \\
1000 \\
\text { grain(g) }\end{array}$ \\
\hline \multicolumn{6}{|c|}{ 2007 Season Experiment } \\
\hline $\begin{array}{l}\text { Weed competition for the whole } \\
\text { season }\end{array}$ & 53.0 & 17.5 & 18.6 & 266.6 & 20.5 \\
\hline $\begin{array}{l}\text { Weed competition for } 4 \text { weeks from } \\
\text { sowing }\end{array}$ & 62.3 & 26.0 & 20.6 & 305.3 & 23.2 \\
\hline $\begin{array}{l}\text { Weed competition for } 6 \text { weeks from } \\
\text { sowing }\end{array}$ & 53.3 & 18.1 & 19.0 & 292.6 & 21.7 \\
\hline $\begin{array}{l}\text { Weed competition for } 8 \text { weeks from } \\
\text { sowing }\end{array}$ & 53.0 & 17.9 & 19.0 & 290.6 & 21.4 \\
\hline $\begin{array}{l}\text { Weed competition for } 10 \text { weeks from } \\
\text { sowing }\end{array}$ & 53.0 & 17.9 & 18.6 & 272.0 & 21.0 \\
\hline Weed free for 4 weeks from sowing & 58.6 & 22.9 & 19.3 & 301.3 & 22.3 \\
\hline Weed free for 6 weeks from sowing & 62.0 & 24.9 & 20.3 & 303.3 & 22.7 \\
\hline Weed free for 8 weeks from sowing & 62.3 & 27.0 & 21.0 & 308.6 & 23.9 \\
\hline Weed free for 10 weeks from sowing & 62.6 & 27.1 & 21.6 & 312.0 & 25.2 \\
\hline Weed free for the whole season & 62.6 & 28.0 & 21.6 & 313.3 & 25.9 \\
\hline L.S.D. at $5 \%$ & 3.00 & 3.54 & 2.65 & 11.27 & 1.29 \\
\hline \multicolumn{6}{|c|}{2008 Season Experiment } \\
\hline $\begin{array}{l}\text { Weed competition for the whole } \\
\text { season }\end{array}$ & 54.0 & 17.1 & 18.6 & 278.3 & 20.7 \\
\hline $\begin{array}{l}\text { Weed competition for } 4 \text { weeks from } \\
\text { sowing }\end{array}$ & 63.6 & 25.9 & 20.6 & 308.0 & 22.9 \\
\hline $\begin{array}{l}\text { Weed competition for } 6 \text { weeks from } \\
\text { sowing }\end{array}$ & 56.3 & 18.1 & 19.3 & 298.6 & 22.2 \\
\hline $\begin{array}{l}\text { Weed competition for } 8 \text { weeks from } \\
\text { sowing }\end{array}$ & 54.6 & 17.6 & 19.0 & 289.3 & 21.6 \\
\hline $\begin{array}{l}\text { Weed competition for } 10 \text { weeks from } \\
\text { sowing }\end{array}$ & 54.3 & 17.8 & 19.0 & 280.0 & 20.9 \\
\hline Weed free for 4 weeks from sowing & 57.6 & 22.6 & 19.3 & 305.3 & 22.6 \\
\hline Weed free for 6 weeks from sowing & 61.6 & 25.1 & 20.0 & 305.6 & 22.8 \\
\hline Weed free for8 weeks from sowing & 63.6 & 28.0 & 21.0 & 308.3 & 24.5 \\
\hline Weed free for 10 weeks from sowing & 64.3 & 28.1 & 21.0 & 312.0 & 24.9 \\
\hline Weed free for the whole season & 64.0 & 28.4 & 21.0 & 314.0 & 25.0 \\
\hline L.S.D. at $5 \%$ & 3.16 & 2.58 & 2.13 & 14.25 & 0.91 \\
\hline
\end{tabular}

This may be due to that the competition of weeds affected crop growth and minimizing the availability of nutrients, water and sunlight. The weed growth there will be one less unit of crop growth. Moreover, it with the establishment of crop plants foliage, they will begin to shade the ground. This shading effect reduced the amount of light available for weed development. Meanwhile, on the other side, weed competition during the whole crop life cycle caused reduction of growth characters were recorded with highest density of weeds. These results coincided with those obtained by Zimdahl (1988); Fofana et al. (1995); Berti et al. (1996); Hamdan et al. (1996); Fofana and Rauber (2000) and EL-Desoki (2003) recorded that the rice plants growth was affected by weed competition. 


\section{II - Effect of weed competition on yield :}

Data presented in Table 3 showed that grain and straw yield per feddan at harvest significantly increased due to weed free and weed removal periods in both seasons. The loss in grain and straw yields due to weed competition 47.2 \& $42.9 \%$ and 38.5 \& $37.6 \%$ in 2007 \& 2008 seasons, respectively as compared with weed free treatments. This may be due to the effective competition of weeds with rice plants particularly in the early stage of rice growth. Removal of weeds at 4 and 6 weeks from sowing then allowed weeds competition for rice until the end season caused grain yield reduction by 17.8 and $12.4 \%, \% \& 12.7$ and $7.7 \%$ in $2007 \& 2008$ seasons, respectively as compared with weed free in whole season, which reached $4.28 \& 4.16$ t/fed.

These treatments significantly produced the highest grain and straw yields per feddan compared with unweeded check in both seasons. The increase in yield induced by weed removal treatments may be due to control of annual weeds at the critical early period, consequently the competition between rice plant and associated weeds was decreased and giving good chance for rice growth and improve the filling of grains resulting heavier grains. These results are coincided with those recorded by Smith (1988); Berti and Zanin (1994); Sattin et al. (1996); Florez et al. (1999); EL-Desoki (2003) and Azmi and Baki (2006).

Table 3: Effect of weed competition duration on yield of broadcasting rice plants at harvest during 2007 and 2008 summer seasons.

\begin{tabular}{|l|c|c|}
\hline \multicolumn{1}{|c|}{$\begin{array}{c}\text { Weed competition \& Weed removal } \\
\text { Times }\end{array}$} & $\begin{array}{c}\text { Straw } \\
\text { yield } \\
\text { (ton/fed) }\end{array}$ & $\begin{array}{c}\text { Grain } \\
\text { yield } \\
\text { (ton/fed) }\end{array}$ \\
\hline 2007 Season Experiment & 3.34 & 2.26 \\
\hline Weed competition for the whole season & 4.89 & 3.82 \\
\hline Weed competition for 4 weeks from sowing & 4.39 & 3.45 \\
\hline Weed competition for 6 weeks from sowing & 3.76 & 2.95 \\
\hline Weed competition for 8 weeks from sowing & 3.43 & 2.60 \\
\hline Weed competition for 10 weeks from sowing & 4.41 & 3.52 \\
\hline Weed free for 4 weeks from sowing & 4.75 & 3.75 \\
\hline Weed free for 6 weeks from sowing & 4.93 & 3.88 \\
\hline Weed free for8 weeks from sowing & 5.31 & 4.16 \\
\hline Weed free for 10 weeks from sowing & 5.43 & 4.28 \\
\hline Weed free for the whole season & 0.23 & 0.06 \\
\hline L.S.D. at 5 \% & & 2.30 \\
\hline \multicolumn{1}{|c|}{ 2008 Season Experiment } & 3.38 & 3.79 \\
\hline Weed competition for the whole season & 4.86 & 3.44 \\
\hline Weed competition for 4 weeks from sowing & 4.38 & 2.97 \\
\hline Weed competition for 6 weeks from sowing & 3.77 & 2.63 \\
\hline Weed competition for 8 weeks from sowing & 3.46 & 3.52 \\
\hline Weed competition for 10 weeks from sowing & 4.41 & 3.72 \\
\hline Weed free for 4 weeks from sowing & 4.72 & 3.87 \\
\hline Weed free for 6 weeks from sowing & 4.92 & 4.16 \\
\hline Weed free for8 weeks from sowing & 5.31 & 0.06 \\
\hline Weed free for 10 weeks from sowing & 5.42 & 0.25 \\
\hline Weed free for the whole season & & \\
\hline L.S.D. at 5 \% & & \\
\hline
\end{tabular}


On the other hand, further delaying of weed removal accentuated the adverse effect of weeds on grain and straw yields at 8 and 10 weeks from sowing caused reduction ranged from 31.1 to $26.3 \%$ and 39.3 to $34.7 \%$ and straw yield ranged from 30.7 to $30.4 \%$ and 36.8 to $36.1 \%$, respectively in both seasons as compared with weed free treatments. Florez et al. (1999); Fofana and Rauber (20000; EL-Desoki (2003) and Azmi and Baki (2006) they reported that, the reduction in grain and straw yields due to increasing of competition was associated weeds with a decreasing number of panicles per square meter and simultaneous increase in the dry matter production of weeds and increase in weed density.

III - Determination the critical period for weed/rice crop competition:1 - Classical (Biological) approach: -

Table 3 and Figure 1 indicated that the critical influence of weeds started to appear on third weeks and ended at eight week after sowing. Obviously, the more the delay of hand weeding was the lowest the grain and straw yield (ton/fed). It can be confirmed that weed competition could seriously affect rice grain yield. Evidently, weed free maintenance for 3 to 8 weeks from sowing is required for good yield. To maintain $95 \%$ of maximum grain yield of rice the maximum time allowed to let weeds grow after crop emergence is 2 and 3 weeks in the first and second season, respectively. The same level could be achieved if the crop kept free from weeds until at least 9.5 and 7.5 weeks after sowing in the first and second season, respectively.

The most important different between as competed species was due to their capacity to intercept the sunlight. So the crop would take a good chance to use sunlight lonely. Furthermore, if the weed were left to compete with rice more than 6 weeks, the severity of competition will increase because the depletion of nutrients from the soil by increased demands of both weeds and rice. These results are in harmony with those obtained by EL-Desoki (2003) and Azmi and Baki (2006) found that the critical period of weed competition in rice occurred during 20 to 60 days from sowing. While, Naidu and Bhan (1980); Kolhe and Mittra (1981); Wells and Cabradilla (1981) and Sahai et al. (1983) they found that the critical weed competition occurs up to $4-9$ weeks after sowing rice. 


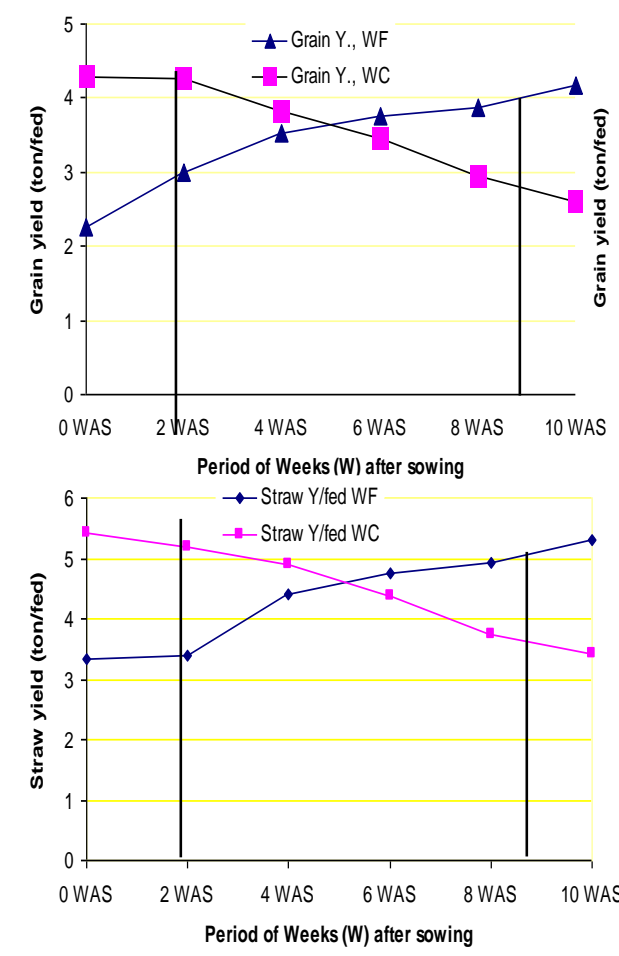

(2007)
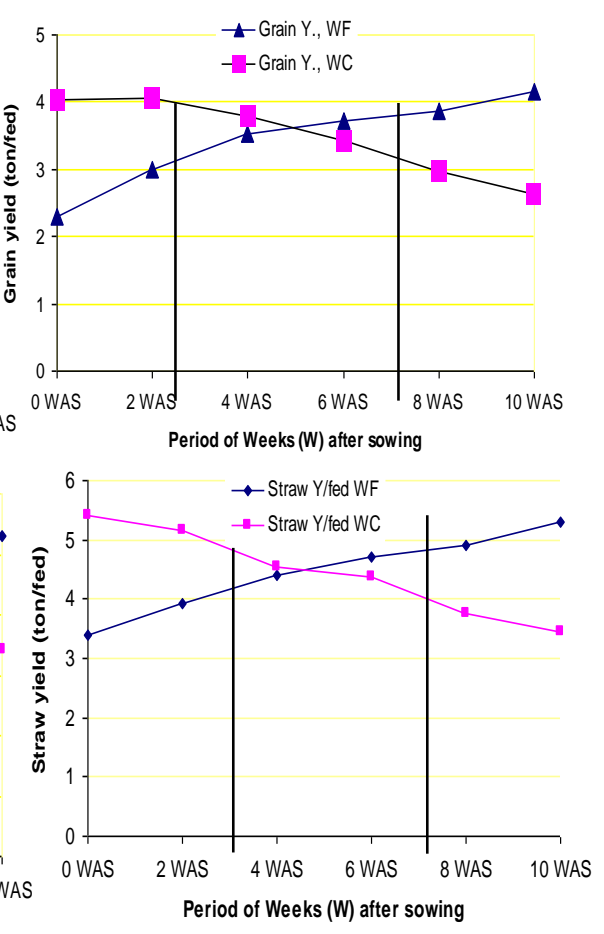

(2008)

Fig. 1: Biological critical period of weed / rice competition on yields.

\section{2- Regression approach (mathematical models): -}

Table 4 show that the relationship between grain, straw yields of rice and period removal was high significantly with linear, logarithmic and quadratic models. The high value of $\mathrm{R}^{2}$ as will as less stander error (SE) was obtained from quadratic model, under weed free \& weed competition condition, respectively.

Examining Table 4 it could be noticed the best model fitted to the yield of weed free and weed competition was quadratic. It had coefficient of determination $\left(\mathrm{R}^{2}\right)$ greater than those of the linear model and logistic. Moreover, values of standard error estimate (SE) of quadratic equation were smaller than those of linear and logistic equation. There fore, the quadratic model worked well for describing the relation between grain yield of rice and weeds under weed free and weed competition in the first and second season.

Fig. 2 and 3 and Tables 4 and 5 show that the effect of times duration of rice crop free from weeds on grain yield ( $t / f e d)$. The relationship between grain yields with the duration of weed free was significant positive and prediction function with value $\mathrm{R}^{2}$ (SE) 0.983 (0.097) and 0.990 (0.101), but, the relationship between grain yields with the duration of weed competition was significant negative and prediction function with value $R^{2}$ (SE) 0.994 (0.053) and 0.993 (0.053), in the first and second seasons, respectively. 
Table 4: The coefficient of determination and their standard errors of three models used to determine the relationships between grain yield with weed-free and weed-competition of 2007 and 2008 seasons.

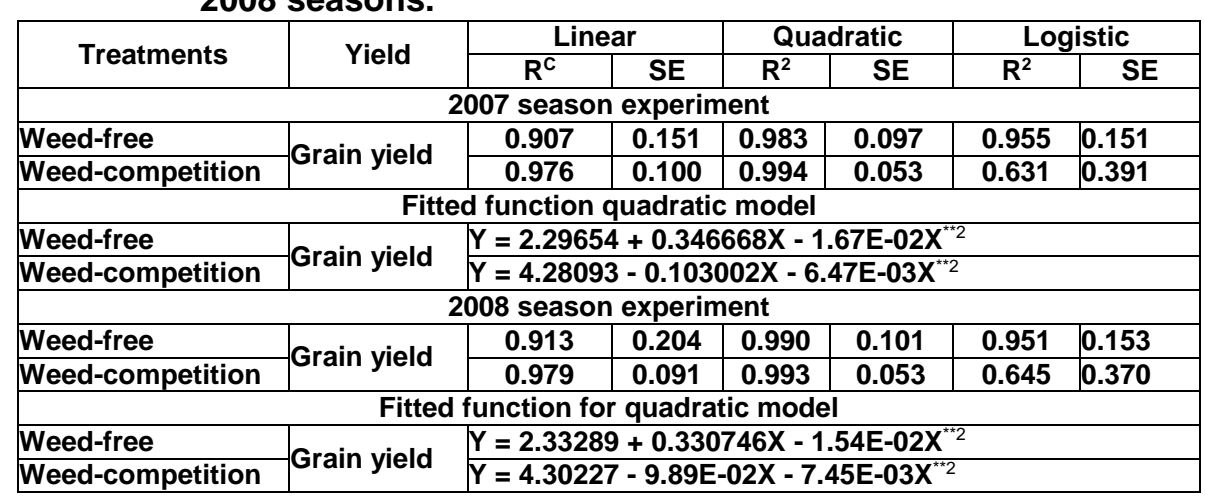

Table 5: Estimation expected grain yield under different weed free and weed competition period.

\begin{tabular}{|c|c|c|c|c|}
\hline \multirow{3}{*}{$\begin{array}{l}\text { Period } \\
\text { (Weeks) }\end{array}$} & \multicolumn{4}{|c|}{ Total yield (ton/fed) } \\
\hline & \multicolumn{2}{|l|}{ Weed free } & \multicolumn{2}{|c|}{ Weed competition } \\
\hline & Grain yield (ton/fed) & $\%$ & Grain yield (ton/fed) & $\%$ \\
\hline \multicolumn{5}{|c|}{2007 season experiment } \\
\hline & \multicolumn{2}{|c|}{$Y=2.29654+0.346668 X-1.67 E-02 X$} & \multicolumn{2}{|c|}{$Y=4.28093-0.103002 X-6.47 E-03 X^{* 2}$} \\
\hline 0 & 2.30 & 56.1 & 4.3 & 100.0 \\
\hline 1 & 2.63 & 64.1 & 4.19 & 97.4 \\
\hline 2 & 2.93 & 71.5 & 4.07 & 94.7 \\
\hline 3 & 3.19 & 77.8 & 3.94 & 91.6 \\
\hline 4 & 3.42 & 83.4 & 3.79 & 88.1 \\
\hline 5 & 3.62 & 88.3 & 3.62 & 84.2 \\
\hline 6 & 3.78 & 92.2 & 3.44 & 80.0 \\
\hline 7 & 3.91 & 95.4 & 3.24 & 75.3 \\
\hline 8 & 4.01 & 97.8 & 3.03 & 70.5 \\
\hline 9 & 4.07 & 99.3 & 2.81 & 65.3 \\
\hline 10 & 4.10 & 100 & 2.57 & 59.8 \\
\hline 11 & 4.10 & 100 & 2.31 & 53.7 \\
\hline 12 & 4.06 & 99 & 2.04 & 47.4 \\
\hline 13 & 3.99 & 97 & 1.76 & 40.9 \\
\hline 14 & 3.88 & 94.6 & 1.46 & 33.9 \\
\hline \multicolumn{5}{|c|}{2008 season experiment } \\
\hline & \multicolumn{2}{|c|}{$Y=2.33289+0.330746 X-1.54 E-02 X^{\prime 2}$} & $Y=4.30227-9.89 E-02 X$ & $5 E-03 X^{* 2}$ \\
\hline 0 & 2.33 & 56.8 & 4.28 & 100.0 \\
\hline 1 & 2.64 & 64.4 & 4.17 & 97.4 \\
\hline 2 & 2.92 & 71.2 & 4.05 & 94.6 \\
\hline 3 & 3.18 & 77.6 & 3.91 & 91.4 \\
\hline 4 & 3.40 & 82.9 & 3.76 & 87.9 \\
\hline 5 & 3.60 & 87.8 & 3.6 & 84.1 \\
\hline 6 & 3.76 & 91.7 & 3.43 & 80.1 \\
\hline 7 & 3.89 & 94.9 & 3.24 & 75.7 \\
\hline 8 & 3.98 & 97.1 & 3.04 & 71.0 \\
\hline 9 & 4.05 & 98.8 & 2.83 & 66.1 \\
\hline 10 & 4.09 & 99.8 & 2.6 & 60.7 \\
\hline 11 & 4.10 & 100 & 2.36 & 55.1 \\
\hline 12 & 4.07 & 99.3 & 2.11 & 49.2 \\
\hline 13 & 4.02 & 98 & 1.85 & 43.2 \\
\hline 14 & 3.93 & 95.9 & 1.56 & 36.4 \\
\hline
\end{tabular}


Tagour, R. M. H. and I. M. EL-Metwally

fig

2590 
To determine the critical period of weed competition to rice crops, the regression approach was used. Application equation reported that to maintain $95 \%$ grain yield of rice earlier weed competition should not allowed exceed 2 weeks from emergence. The same situation the late duration of weed free period should not exceed 7 weeks from emergence.

Examining Table 6 it could be noticed the best model fitted to the yield of weed free and weed competition was quadratic. It had coefficient of determination $\left(\mathrm{R}^{2}\right)$ greater than those of the linear model and logistic. Moreover, values of standard error estimate (SE) of quadratic equation were smaller than those of linear and logistic equation. There fore, the quadratic model worked well for describing the relation between straw yield of rice and weeds under weed free and weed competition in the first and second season.

Table 6: The coefficient of determination and their standard errors of three models used to determine the relationships between straw yield with weed-free and weed-competition of 2007 and 2008 seasons.

\begin{tabular}{|c|c|c|c|c|c|c|c|}
\hline \multirow[b]{2}{*}{ Treatments } & \multirow[b]{2}{*}{ Yield } & \multicolumn{2}{|c|}{ Linear } & \multicolumn{2}{|c|}{ Quadratic } & \multicolumn{2}{|c|}{ Logistic } \\
\hline & & $R^{2}$ & SE & $\mathbf{R}^{2}$ & SE & $\mathbf{R}^{2}$ & SE \\
\hline \multicolumn{8}{|c|}{2007 season experiment } \\
\hline \multirow{2}{*}{\begin{tabular}{|l} 
Weed-free \\
Weed-competition
\end{tabular}} & \multirow{2}{*}{ Straw yield } & 0.879 & 0.249 & 0.899 & 0.237 & 0.823 & 0.301 \\
\hline & & 0.973 & 0.128 & 0.986 & 0.096 & 0.635 & 0.473 \\
\hline \multicolumn{8}{|c|}{ Fitted function quadratic model } \\
\hline Weed-free & \multirow[t]{2}{*}{ Straw yield } & $Y=3.385$ & +0.26 & $\frac{153 X-8}{6-8}$ & 53E-03) & & \\
\hline \multirow{2}{*}{\multicolumn{6}{|c|}{2008 season experiment }} & & \\
\hline \multirow{2}{*}{\begin{tabular}{|l|} 
Weed-free \\
Weed-competition \\
\end{tabular}} & \multirow{2}{*}{ Straw yield } & 0.864 & 0.259 & 0.879 & 0.255 & & 0.315 \\
\hline & & 0.976 & 0.118 & 0.986 & 0.094 & 0.548 & 0.453 \\
\hline \multicolumn{8}{|c|}{ Fitted function for quadratic model } \\
\hline Weed-free & \multirow{2}{*}{ Straw yield } & \multirow{2}{*}{\multicolumn{6}{|c|}{\begin{tabular}{|l}
$Y=3.42359+0.248473 X-7.28 E-03 X X^{* 2}$ \\
$Y=5.44600-0.138607 X-6.65 E-03 X^{* 22}$
\end{tabular}}} \\
\hline Weed-competition & & & & & & & \\
\hline
\end{tabular}

Fig. 4 and 5 and Table 6 The relationship between straw yield with the duration of weed free had similar trend of grain yield where is significant and positive and prediction function value $\mathrm{R}^{2}$ (SE) 0.899 (0.237) and 0.879 (0.255), but, the relationship between straw yields with the duration of weed competition was significant and negative and prediction function with value $\mathrm{R}^{2}$ (SE) $0.986(0.096)$ and 0.986 (0.094 in the first and second seasons, respectively.

\section{Conclusion:}

It could be concluded depending on the use of biological and regression approaches that both weed free and weed competition duration show that the relationship with weed - free periods and the duration of weed competition periods fit with quadratic functions and the critical period of weed competition in broadcasted rice from the above models were among between $2-7$ weeks from rice sowing, thus it's important to remove the weeds at this time for maintain the maximum grain yield potential. 


\section{REFERENCES}

Azmi, M. and B. B. Baki (2006). Weed flora landscapes and innovative management in direct-seeded culture. International Rice Congress 2006, Proceedings of the Second International Rice Congress, pp. 5055. New Delhi, India.

Berti, A. and G. Zanin (1994). Density equivalent: a method for forecasting yield loss caused by mixed weed populations. Weed Res., 34: 327-332.

Berti A.; C. M. Dunan; M. Sattin; G. Zanin and P. Westra (1996). A new approach to determine when to control weeds. Weed Sci., 44: 496-503.

Burnside, O. C.; M. J. Wiens; B. J. Holder; S. Weisberg; E. A. Ristau; M. M. Johnson and J. H. Cameron (1998). Critical periods for weed control in dry beans (Phaseolus vulgaris). Weed Science, 46 (3): 301-306.

Cousens, R. D. (1985a). A simple model relating yield loss to weed density. Annals Applied Biology. 107:239-252.

Dawson, J. H. (1970). Time and duration of weed infestation in relation to weed-crop competition. Proc. South. Weed Sci. Soc. 23:13-25.

EL-Desoki, E. R. (2003). Weed competition in the field of direct seeded rice. Bull. NRC, Egypt. 28 (4): 527-534.

Fofana, B. and R. Rauber (2000). Weed suppression ability of upland rice under low-input conditions in west Africa. Weed Res., Oxford 40 (3):271-280.

Fofana, B.; T. Koupur; M. P. Jones; and D. F. Johnson (1995). The development of rice varieties competitive with weeds. Brighton of Crop protection Conf. Weeds. UK. 20-23 November. Vol. (1): 187-192.

Florez, J. A.; A. J. Fischer; H. Ramirez and M. C. Duque (1999). 'Predicting rice yield losses caused by multispecies weed competition' Published in Agron. J., 91:87-92.

Gogoi, A. K.; H. Brown; Gw. Cussans; Md. Devine; So. Duke; Q. C. Fernandez; A. Helweg; Re. labrada; M. landes; P. Kudsk and J. C. Streibig (1996). Integrated weed management of rice in high rainfall region of India. Proce. Of the second international weed control congress. Copenhagen. Denmark. 25-28 June ; Volumes (1-4): 715719.

Hamdan, P.; M. Mashhor and H. Watanabe (1996). Yield component analysis of direct seeded rice under several densities of red sprangletop [ leptochloa chinensis (L) Neesj in eninsular Malaysia. Weed Res., Japan. (4) 3: 216.

Karim, S. M. R.; T. M. T. Iqbal and N. Islam (1998). Relative yield of crops. Pakistan J. of Scientific and Indus., Res., (41): 316-318.

Knezevic, S. Z. (2000). The concept of critical period of weed control. Pages 30-40 in S. Z. Knezevic, ed, integrated weed management. Mead, NE: co operative Extention, University of Nebraska. [the work shop material].

Knezevic, S. Z.; S. R. Evans; E. E. Blankenship and J. L. Lindquist (2002). Critical period for weed control: the concept and data analysis. Weed Sci., 50: 773-786. 
Kolhe, S. S. and B. N. Mittra (1981). Weed control in direct seeded upland rice. Page 67-72 in proceedings $8^{\text {th }}$ Asian Pacific Weed Sci., Soc. Conf. Bangalore, India.

Mekky, M. S.; A. A. Atia and M. F. I. Daie (2005). Three approaches for estimation critical period in onion crop. Egypt. J. of Appl. Sci., 20 (11 B): 474-489.

Naidu, N. G. and V. M. Bhan (1980). Effect of different groups of weeds and periods of weed free maintenance on the grain yields of drilled rice. Indian J., Weed Sci., 12: 151-157.

Nieto, J. H.; M. A. Brondo and J. T. Gonzalez (1968). Critical periods of the crop growth cycle for competition from weeds. PANS 14:159-166.

Sahai, B.; V. M. Bhan and R. S. Balyan (1983). Weed emergence and competition in drilled upland rice in India. Trop. Pest Manage., 29 (2): $125-128$.

Sattin, M.; A. Berti and G. Zanin (1996). Crop yield loss in relation to weed time of emergence and removal: analysis of the variability with mixed infestations. Proc. of the Second Int. Weed Control Congress, Copenhagen. pp. 67-72.

Smith, R. J. (1988). Weed thresholds in Southern U.S. rice, Oryza sativa. Weed Technol. 2:232-241.

Singh, M.; M. C. Saxena A. B. E. Abu-Irmaileh S. A. Al-Thabbi and N. I. Haddad (1996). Estimation of critical period of weed control. Weed Science, Vol (44): 273-283.

Snedecor, G. W. and W. G. Cochran (1967). Statistical Methods. lowa State Univ., USA, Press, Ames 593.

Vega, M. N.; J. D. Ona and E. P. Palter (1967). Weed control in upland rice at the Univ. of the Philippine College of Agricultural, 51: 397 - 411.

Wells, G. J. and N. Cabradilla (1981). Weed competition in upland rice. Proc. of the $8^{\text {th }}$ Asian Pacific Weed Sci., Soc. Conf. Bangalore, India. pp 143144 Bangalore, India.

Zimdahl, R. L. (1988). The concept and application of the critical weed-free period. In Altieri, M. A. and M. Liebmann eds. Weed Management in Agroecosystems: Ecological Approaches. pp. 145-155. CRC Press, Boca Raton. Florida, USA.

النماذج الرياضية للفترة الحرجة لمنافسة الحشائش في زراعات الأرز البدار . 
Tagour, R. M. H. and I. M. EL-Metwally

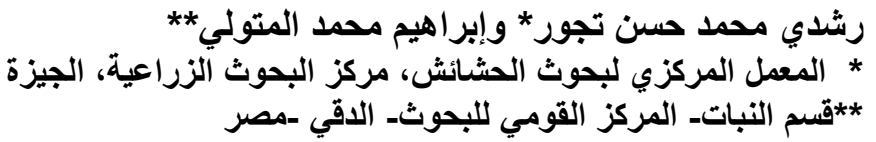

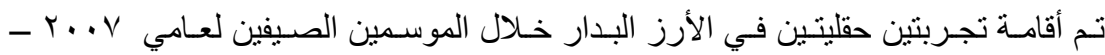

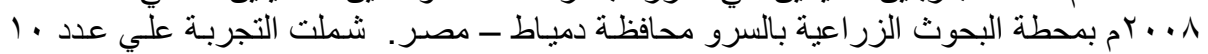

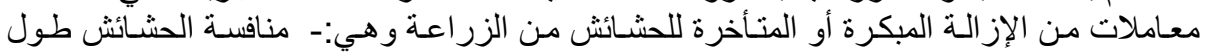

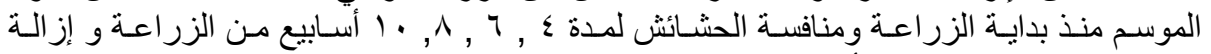

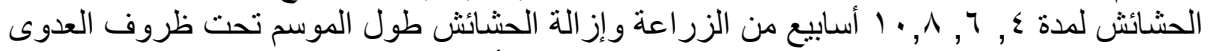

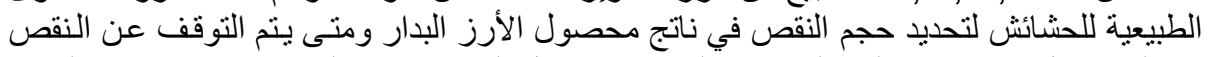

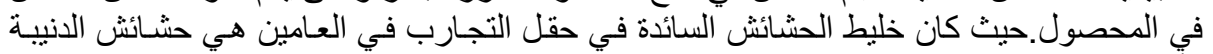

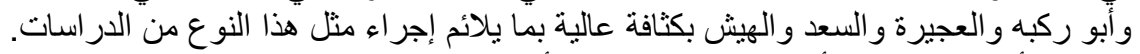

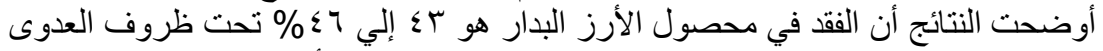

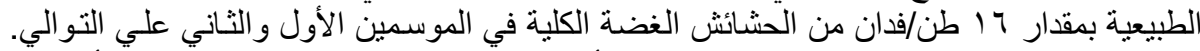

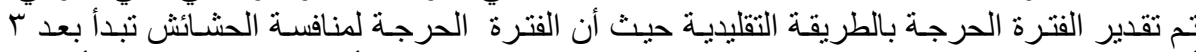

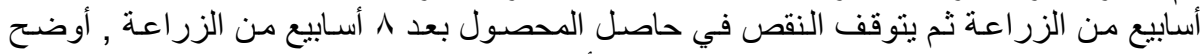

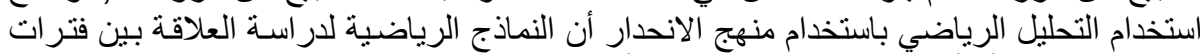

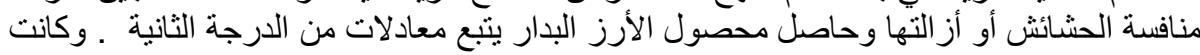

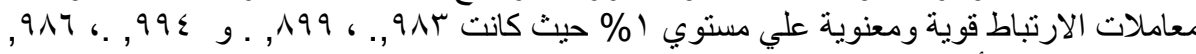

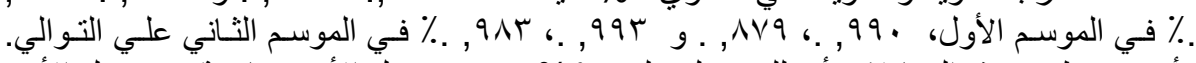

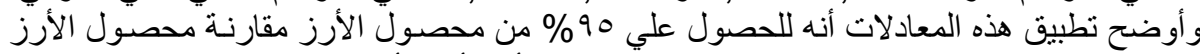

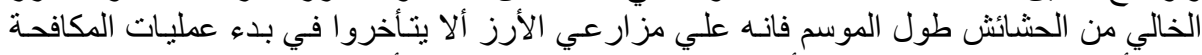

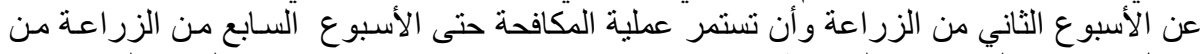

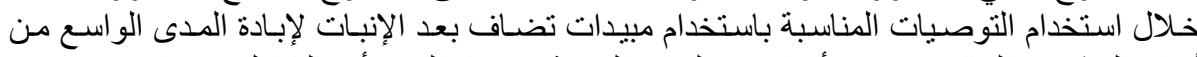
أنو اع الحشائش المذكورة سابقا أو إجراء النقاوة اليدوية في هذه الفترة أو التكامل بينهما.

كلية الزراعة - جامعة المنصورة مركز البحوث الزراعية
قام بتحكيم البحث

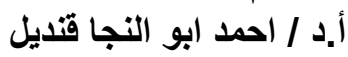

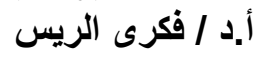

